\title{
Pengaruh Model Pembelajaran Project Based Learning (Pjbl) terhadap Kemampuan Berpikir Kreatif dalam Pembelajaran Tematik Muatan Pelajaran IPA Peserta Didik Kelas V SD Negeri
}

\author{
Arida Febriyanti \\ Program Magister Pendidikan Dasar Universitas Bengkulu. \\ aridafebriyanti@rocketmail.com
}

\section{Agus Susanta}

Program Magister Pendidikan Dasar Universitas Bengkulu.

\section{Abdul Muktadir}

Program Magister Pendidikan Dasar Universitas Bengkulu.

\begin{abstract}
Penelitian ini bertujuan untuk mengetahui pengaruh model pembelajaran PjBL terhadap kemampuan berpikir kreatif dalam pembelajaran Tematik muatan pelajaran IPA peserta didik kelas V SD Negeri. Penelitian ini merupakan penelitian kuantitatif. Metode yang digunakan ialah quasy experiment. Desain pada penelitian ini yaitu The Matching Only Pretest-Posttes Control Group Design. Populasi dalam penelitian ini adalah seluruh peserta didik kelas V di SD Negeri Gugus I Kecamatan Arga Makmur Kabupaten Bengkulu Utara terakreditasi A. Sampel dalam penelitian ialah siswa kelas VC SDN 009 Bengkulu Utara berjumlah 21 orang sebagai kelas eksperimen, dan SDN 016 Bengkulu Utara berjumlah 21 orang sebagai kelas kontrol. Instrumen yang digunakan berupa tes tertulis terdiri atas dimensi kemampuan berpikir lancar (fluency), kemampuan berpikir luwes (flexibility), kemampuan berpikir orisinil (originality), kemampuan berpikir merinci (elaboration), dan kemampuan berpikir menilai (evaluation). Untuk mendeskripsikan proyek pop up book menggunakan lembar observasi tahapan proses dan tahapan hasil proyek. Hasil penelitian menunjukkan bahwa terdapat pengaruh signifikan model pembelajaran PjBL terhadap kemampuan berpikir kreatif dalam pembelajaran tematik muatan pelajaran IPA peserta didik kelas V SD Negeri. Penelitian ini juga menghasilkan proyek pop up book dua dimensi dengan baik sehingga berpengaruh terhadap dimensi kemampuan berpikir lancar (fluency), kemampuan berpikir luwes (flexibility), kemampuan berpikir orisinil (originality
\end{abstract}




\title{
Pengaruh Model Pembelajaran Project Based Learning (Pjbl) terhadap Kemampuan Berpikir Kreatif dalam Pembelajaran Tematik Muatan Pelajaran IPA Peserta Didik \\ Kelas V SD Negeri
}

\author{
kemampuan berpikir merinci (elaboration), kemampuan berpikir menilai \\ (evaluation).
}

Kata Kunci : Model Pembelajaran Project Based Learning, Berpikir Kreatif, IPA

\section{Pendahuluan}

Pesatnya kemajuan teknologi dan komunikasi melahirkan pendidikan abad 21 yang menuntut kemampuan dan keahlian. Cara pandang pembelajaran dari sistem pembelajaran yang berpusat dari guru (teaching centered learning) terhadap pembelajaran berpusat pada siswa(student centered learning), belajar mandiri (selfdirected learning), dan pemahaman diri (metakognisi). Hal tersebut perlu adanya pengembangan sumber daya manusia yang berkompeten. Rancangan UNESCO melalui empat pilar pendidikan menyongsong abad 21 diantaranya; 1) belajar untuk mengetahui (learning to how, 2) belajar untuk melakukan (learning to do), 3) belajar untuk mengaktualisasikan diri sebagai individu mandiri yang berkepribadian (learning to be), 4) belajar untuk hidup bersama (learning to live together) menuntut peserta didik memiliki keterampilan, pengetahuan, dan kemampuan di bidang teknologi, informasi dan komunikasi.

Learning to do mengajarkan peserta didik untuk belajar melakukan kegiatan pembelajaran dengan melakukan secara langsung, sehingga peserta didik akan terbekali keterampilan dalam berbuat sesuatu, mengembangkan kemampuan bereksplorasi, menumbuhkan rasa ingin tahu, inisiatif dan kreativitas. Hosnan (2014:21), mengemukakan bahwa setidaknya terdapat empat dasar pembentuk daya kreativitas yaitu; 1) keingintahuan dalam mengerjakan sesuatu dengan lebih baik, mengendalikan dorongan dalam mencipta atau bereksperimen (coriosity), 2) keterbukaan dalam gagasan dan ide baru dan bersikap positif untuk mencoba halhal baru yang ditemuinya (openness), 3) keberanian mengambil resiko terhadap mengambil gagasan/ide (risk), 4) energi sebagai pendorong kerja dan pemacu hasrat (energy).

Sebenarnya kreativitas peserta didik tidak rendah, hanya saja kurang diorganisir oleh pendidik dalam proses pembelajaran secara langsung untuk melakukan sesuatu hal. Kendala dalam mengembangkan kreativitas peserta didik yaitu pengajaran yang konvergen, sikap dan keyakinan pendidik terhadap kreativitas peserta didik, motivasi lingkungan, maupun keyakinan peserta didik sendiri terhadap kreativitas dirinya sendiri. Untuk mewujudkan hal itu, maka diperlukan keterampilan pendidik dalam menentukan dan mengembangkan strategi dan model pembelajaran yang dapat meningkatkan kemampuan berpikir kreatif peserta didik (Siswono,2018:3-4).

Model pembelajaran yang diperlukan ialah model pembelajaran yang memungkinkan keterbudayakannya kecakapan berpikir sains, terkembangnya "sense of inquiry" dan kemampuan berpikir kreatif peserta didik (Sulaeman, 2016:3). Banyak model pembelajaran yang mendukung kurikulum 2013 salah satunya ialah PjBL, model ini merupakan pembelajaran yang berpusat pada proses, berjangka waktu, berfokus pada masalah dan melibatkan peserta didik untuk memecahkan masalah melalui metodeilmiah.

Sulaeman (2016:7) menyatakan bahwa, terdapat tiga hal yang perlu dipertimbangkan dalam melakukan penilaian proyek berupa a) kemampuan pengelolaan, b) relevansi, c) keaslian.

Tujuan penelitian secara umum ialah untuk mengetahui pengaruh penggunaan model PjBL terhadap kemampuan berpikir kreatif dalam pembelajaran Tematik muatan pelajaran IPA pada peserta didik kelas V SD Negeri. Adapun tujuan penelitian secara khusus padapenelitian ini ialah; 1) untuk mendeskripsikan 
kualitas proyek yang dihasilkan sebagai karya dari model PjBL, 2) untuk mengetahui pengaruh penggunaan model $\mathrm{PjBL}$ terhadap kemampuan berpikir kreatif dimensi kemampuan berpikir lancar, luwes, orisinil, merinci, dan menilai dalam pembelajaran Tematik muatan pelajaran IPA pada peserta didik kelas V SD Negeri.

\section{Metode}

Metode yang digunakan ialah eksperimen semu (quasy experiment), Desain pada penelitian ini adalah The Matching Only Pretest-Posttes Control Group Design. Populasidalam penelitian ini adalah seluruh peserta didik kelas V di SD Negeri Gugus I Kecamatan Arga Makmur Kabupaten Bengkulu Utara terakreditasi A. Sampel pada penelitian ini ialah peserta didik kelas VA SDN 016 Bengkulu Utara sebagai kelas kontrol berjumlah 21 orang, dan peserta didik kelas VC SDN 009 Bengkulu Utara sebagai kelas eksperimen berjumlah 21 orang.

Instrumen yang digunakan berupa tes tertulis terdiri dari kemampuan berpikir kreatif dimensi: kemampuan berpikir lancar, luwes, orisinil, merinci, dan menilai. Sedangkan untuk mendeskripsikan proyek pop up book menggunakan lembar observasi tahapan proses dan tahapan hasil penyelesaian proyek.

Materi siklus air pada tema 8 (lingkungan sahabat kita) sub tema 1 (manusia dan lingkungan) pembelajaran 2 dapat dijadikan sebuah proyek dengan membuat pop up book secara berkelompok sehingga peserta didik mengalami secara langsung, menumbuhkan kreativitas dan akan selalu terkenang dalam ingatannya. Seperti diungkapkan oleh Siregar dan Nara (2011:33), proses belajar akan berjalan dengan baik dan kreatif jika pendidik memberikan kesempatan kepada peserta didik untuk menemukan sesuatu konsep, teori, definisi melalui sumbernya.

Hasil tes dianalisis secara kuantitatif dan kualitatif. Uji hipotesis dilakukan dengan menggunakan uji paired sampel t-test menggunakan program SPSS 22.

\section{Hasil}

Bagian hasil menyajikan hasil dari pengolahan dan analisis data agar data menjadi lebih mudah untuk dipahami dan ditafsirkan. Hasil dapat disajikan secara kategorial, deskriptif kata-kata, deskriptif angka (statistik), tabel, grafik, bagan, hasil uji perbandingan, uji korelasi, dan lain sebagainya.

\section{Pembahasan}

Bagian pembahasan berisi hasil penafsiran atas hasil penelitian yang telah diperoleh. Bagian ini juga berisi hasil pembandingan antara hasil penelitian dengan teori yang mendukungnya serta temuan penelitian-penelitian lain yang relevan. Hasil pembandingan dengan teori ini dapat terlihat apakah hasil penelitian ini mendukung dan memperkuat teori yang sudah ada atau malah bertolak belakang dengan teori tersebut

Hasil penelitian diperoleh dari analisis yang dilakukan terhadap hasil jawaban pretest dan posttest. Hasil pretest yang dilakukan terhadap sampel menunjukkan belum terdapat perbedaan yang signifikan antara kelas eksperimen dan kelas kontrol. Setelah pretest dilakukan, peneliti melakukan pembelajaran pada kelas eksperimen dengan menggunakan model pembelajaran PjBL, sedangkan kelas kontrol menggunakan pembelajaran konvensional (eksplorasi, elaborasi, dan 


\section{Pengaruh Model Pembelajaran Project Based Learning (Pjbl) terhadap Kemampuan \\ Berpikir Kreatif dalam Pembelajaran Tematik Muatan Pelajaran IPA Peserta Didik}

Kelas V SD Negeri

konfirmasi) tetapi memenuhi kriteria standar proses yang sesuai dengan Permendiknas Nomor 41 tahun 2007.

Menurut Ngalimun (2018:194), model pembelajaran PjBL adalah model pembelajaran yang inovatif, berfokus pada konsep dan prinsip utama dari suatu disiplin, melibatkan peserta didik dalam kegiatan pemecahan masalah dan tugastugas bermakna, memberi peluang siswa bekerja secara otonom, membangun dan menemukan pengetahuan belajar mereka sendiri dan puncaknya menghasilkan produk karya peserta didik bernilai dan realistis. Abidin (2014:168), menyatakan bahwa model pembelajaran PjBL memiliki tujuh karakteristik sebagai berikut; 1) melibatkan peserta didik secara langsung dalam pembelajaran; 2) menghubungkan pembelajaran dengan dunia nyata; 3) dilaksanakan dengan berbasis penelitian; 4) melibatkan berbagai sumber penelitian; 5) bersatu dengan pengetahuan dan keterampilan; 6) dilakukan dari waktu ke waktu; 7) diakhiri dengan sebuah produk tertentu.

Sulaeman (2016:19), menyatakan sintak model pembelajaran PjBL dan dimensi kemampuan berpikir kreatif ialah; 1) memulai dengan memberikan pertanyaan penting (start with essential question), 2) mendesain perencanaan untuk proyek (desain aplan for the project), 3) membuat jadwal (creates a schedule), 4) memantau peserta didik dan kemajuan proyek (monitor the students and the progress of the project), 5) menilai hasil (assess the outcome), dan 6) mengevaluasi pengalaman (evaluate the experience). Kemampuan berpikir kreatif memiliki lima dimensi yaitu; 1) kemampuan berpikir lancar (fluency), 2) kemampuan berpikir luwes (flexibility), 3) kemampuan berpikir orisinil (originality), 4) kemampuan berpikir merinci (elaboration), dan 5) kemampuan berpikir menilai (evaluation). Keefektifan PjBL dapat diketahui dari hasil rata-rata nilai kemampuan berpikir kreatif pada Tabel 1.

Tabel 1. Rata-rata nilai model PjBL

terhadap kemampuan berpikir kreatif

\begin{tabular}{|c|c|c|c|c|c|c|}
\hline \multirow{3}{*}{$\begin{array}{l}\text { Berpikir } \\
\text { Kreatif }\end{array}$} & \multicolumn{6}{|c|}{ Rata-raita Nillai Pescrtia Didik } \\
\hline & \multicolumn{3}{|c|}{$\begin{array}{l}\text { Pembelujaran } \\
\text { konvensional } \\
\text { Kelas kontrol }\end{array}$} & \multicolumn{3}{|c|}{$\begin{array}{l}\text { Pembelajaram PjBL } \\
\text { Kelas ekspenimen }\end{array}$} \\
\hline & pune & prosit & N- & pret & poust & No- \\
\hline Lancar & $\exists \mathrm{B}, 1$ & 62,3 & 0.39 & 40 & 85,7 & 0.76 \\
\hline Luwes: & 35,6 & 54,9 & 0,29 & 33 & $7 \mathbb{1 1}$ & 0.56 \\
\hline Orisinill & 34 & 53,1 & 0,28 & 38,1 & 70.7 & 0.54 \\
\hline Merinci & 44,7 & 55 & $0.1 \mathrm{~s}$ & 38.1 & 69,7 & 0.511 \\
\hline Menillai & 44 & 55 & 0,19 & 47 & 73 & 0.49 \\
\hline Total & 1196 & 280 & 1,3 & 196 & 370 & 2,9 \\
\hline Ratia-rata & 39.2 & 56 & 0,26 & 39,2 & 74 & 0.58 \\
\hline
\end{tabular}

Berdasarkan hasil analisis pada Tabel 1 dan kategori tingkat N-Gain menunjukkan bahwa secara total kemampuan berpikir kreatif pada kelas eksperimen jauh lebih tinggi dari kelas kontol. Secara rinci kategori N-Gain kelas eksperimen dimensi berpikir lancar mencapai kategori tinggi sebesar 0,76, sedangkan dimensi berpikir luwes $(0,56)$, orisinil $(0,54)$, merinci $(0,51)$, dan menilai $(0,49)$ dengan kategori sedang. Secara keseluruhan N-Gain kelas eksperimen sebesar 0,58 dengan kategori sedang. Hal tersebut dikarenakan hanya dimensi berpikir lancar yang mendapatkan kategori tinggi, empat dimensi lainnya mendapatkan kategori sedang.

Pada kelas kontrol kategori NGain dimensi berpikir lancar sebesar 0,39 dengan kategori sedang, sedangkan dimensi berpikir luwes $(0,29)$, orisinil $(0,28)$, merinci $(0,18)$, dan menilai $(0,19)$ dengan kategori rendah. Secara keseluruhan N-Gain kelas 
kontrol sebesar 0,26 dengan kategori sedang. Hal tersebut terjadi dikarenakan hanya dimensi berpikir lancar yang mendapatkan kategori sedang, empat dimensi mendapatkan kategori rendah.

Kelebihan PjBL meningkatkan kemampuan berpikir kreatif dikarenakan PjBL memiliki kelebihan yaitu 1) mempersiapkan peserta didik menghadapi kehidupan nyata yang terus berkembang, 2) meningkatkan motivasi peserta didik untuk belajar dan mendorong kemapuan mereka untuk melakukan pekerjaan penting, 3) menghubungkan pembelajaran di sekolah dengan dunia nyata, 4) membentuk sikap kerja peserta didik, 5) meningkatkan kemampuan komunikasi dan sosial peserta didik, 6) meningkatkan kemampuan peserta didik dalam pemecahan berbagai

masalah yang dihadapi, 7) meningkatkan keterampilan peserta didik untuk menggunakan informasi dengan beberapa disiplin ilmu yang dimilikinya, 8) meningkatkan kepercayaan diri peserta didik, 9) meningkatkan kemampuan peserta didik menggunakan teknologi dalam belajar (Priansa, 2017:211-212).

Dendeskripsi kualitas karya pop up book dua dimensi menggunakan instrumen penilaian proyek pop up book berupa lembar observasi. Terdapat indikator penilaian kualitas proyek yang terdiri dari dua tahapan yaitu tahapan proses dan tahapan penyelesaian proyek, dari dua tahapan

tersebut mencakup tiga aspek yaitu aspek kemampuan pengelolaan, aspek relevansi, dan aspek keaslian. Tahapan proses pada aspek kemampuan pengelolaan mencakup kemampuan peserta didik dalam mempersiapkan alat dan bahan serta prosedur pembuatan proyek secara

sistematis.

Pada tahapan proses aspek kemampuan pengelolaan, penilaian proyek pop up book dilakukan oleh observer. Adapun penilaian observer pada Tabel 2.

Tabel 2. Penilaian Proyek pop up book dua dimensi

\begin{tabular}{|c|c|c|c|c|c|c|c|}
\hline \multirow{2}{*}{ Taha-pan } & \multirow{2}{*}{ Aspek } & \multirow{2}{*}{ Indika-tor } & \multicolumn{5}{|c|}{ Kelompok } \\
\hline & & & 1 & 2 & 3 & 4 & 5 \\
\hline \multirow[t]{2}{*}{ Proses } & \multirow[t]{2}{*}{$\begin{array}{l}\text { Kemam- } \\
\text { puan } \\
\text { Pengelolaan }\end{array}$} & $\begin{array}{l}\text { Kelengkapan } \\
\text { mempersiapkan alat dan } \\
\text { bahan }\end{array}$ & SB & SB & SB & SB & SB \\
\hline & & $\begin{array}{l}\text { Melakukan langkah- } \\
\text { langkah/ } \\
\text { pembuatan } \\
\text { matis }\end{array}$ & SB & SB & B & B & SB \\
\hline \multirow{2}{*}{$\begin{array}{l}\text { Penye- } \\
\text { lesaian } \\
\text { Proyek }\end{array}$} & Relevansi & $\begin{array}{l}\text { Menjawab soal dalam } \\
\text { mengerjakan LKPD }\end{array}$ & $\begin{array}{c}\mathrm{B} \\
(79)\end{array}$ & $\begin{array}{c}\text { B } \\
(79)\end{array}$ & $\begin{array}{c}\mathrm{C} \\
(71)\end{array}$ & $\begin{array}{c}\text { B } \\
(86)\end{array}$ & $\begin{array}{c}\mathrm{C} \\
(71) \\
\end{array}$ \\
\hline & Keaslian & Karya kreatif & SB & B & $\mathrm{B}$ & SB & $\mathrm{B}$ \\
\hline
\end{tabular}

Dari Tabel 2, menunjukkan bahwa pada tahapan proses aspek kemampuan pengelolaan indikator 1) kelengkapan mempersiapkan alat dan bahan memiliki predikat sangat baik, 2) melakukan langkah-langkah/ prosedur pembuatan secara sistematis memiliki predikat sangat baik danbaik. Tahapan penyelesaian proyek aspek relevansi indikator menjawab soal LKPD memiliki predikat baik dan cukup. Aspek keaslian indicator karya kreatif memiliki predikat sangat baik dan baik. Safri, Sari, dan Marlina (2017) mengemukakan bahwa pop up book merupakan media pembelajaran yang mempunyai daya tarik terhadap perserta didik dikarenakan menyajikan visualisasi dengan bentuk-bentuk yang dibuat dengan melipat, bergerak, dan muncul kehingga memberikan kejutan dan kekaguman bagi peserta didik. Sejalan dengan pendapat tersebut, Siregar dan Nara, (2011:146) menyatakan bahwa proyek dapat digunakan untuk mengetahui pemahaman, pengetahuan dan kemampuan peserta didik dalam menginformasikan subyek tertentu secara jelas. 
Pengujian hipotesis penelitian yang dilakukan dengan menggunakan uji paired sampel t-test menggunakan program SPSS 22 dapat dilihat pada Tabel 3.

Tabel 3. Hasil perhitungan Uji-t

\begin{tabular}{|l|c|c|c|c|}
\hline Kemampuan & $\mathbf{T}_{\text {mans }}$ & $d f$ & $\begin{array}{c}\text { Sig. } \\
(2- \\
\text { tailed) }\end{array}$ & $\begin{array}{c}\text { Eta } \\
\text { squared } \\
\text { \# }\end{array}$ \\
\hline $\begin{array}{l}\text { Berpikir } \\
\text { lancar }\end{array}$ & 11,433 & 40 & 0,000 & 0,86 \\
\hline $\begin{array}{l}\text { Berpikir } \\
\text { luwes }\end{array}$ & 7,653 & 40 & 0,000 & 0,74 \\
\hline $\begin{array}{l}\text { Berpikir } \\
\text { orisinil }\end{array}$ & 5,442 & 40 & 0,000 & 0,59 \\
\hline $\begin{array}{l}\text { Berpikir } \\
\text { merinci }\end{array}$ & 5,357 & 40 & 0,000 & 0,58 \\
\hline $\begin{array}{l}\text { Berpikir } \\
\text { menilai }\end{array}$ & 5,510 & 40 & 0,000 & 0,60 \\
\hline keterangan : efek perlakuan karegori
\end{tabular}

besar.

Berdasarkan Tabel 3 di atas, menunjukkan perolehan nilai thitung lebih besar dari ttabel pada taraf signifikan a $=5 \%$ sebesar 1,684 , dapat disimpulkan thitung $>$ ttabel maka Ha diterima. Terdapat pengaruh yang signifikan model pembelajaran PjBL terhadap kemampuan berpikir kreatif dimensi kemampuan berpikir lancar, luwes, orisinil, merinci, dan menilai dalam pembelajaran Tematik muatan pelajaran IPA peserta didik Kelas V SD Negeri dengan pengaruh perlakukan kategori besar.

Hal tersebut sesuai dengan hasil penelitian Arisanti, Wahyu dan Ari (2016:82-95) bahwa terdapat peningkatan keterampilan berpikir kreatif menggunakan model PjBL yang lebih baik dari kelas yang menggunakan model konvensional. Sejalan dengan pendapat tersebut, Kusumaningrum dan Djukri (2016:242), menyatakan bahwa, model pembelajaran PjBL sangat baik dalam mengembangkan keterampilan membuat keputusan, kemampuan berkreativitas, dan kemampuan memecahkan masalah.

\section{Kesimpulan}

Berdasarkan data hasil penelitian, pengolahan data, analisis dan pembahasan data maka terdapat pengaruh signifikan penggunaan model pembelajaran PjBL terhadap kemampuan berpikir kreatif dalam pembelajaran Tematik muatan pelajaran IPA peserta didik kelas V SD Negeri. Secara rinci dapat dikemukakan sebagai berikut ini.

1. Kualitas yang dihasilkan sebagai karya dari model PjBL menunjukkan hasil bahwa peserta didik telah baik dalam menghasilkan sebuah karya pop up book dua dimensi dan membatu memahami materi yang dipelajari sehingga menghadirkan kesan konkret dalam pembelajaran.

2. Terdapat pengaruh yang signifikan secara statistik (taraf a=5\%) model pembelajaran PjBL terhadap kemampuan berpikir lancar (fluency) dalam pembelajaran Tematik muatan pelajaran IPA peserta didik Kelas V SD Negeri dengan pengaruh perlakuan kategori besar $(0,86)$.

3. Terdapat pengaruh yang signifikan secara statistik (taraf $a=5 \%$ ) model pembelajaran PjBL terhadap kemampuan berpikir luwes (flexibility) dalam 
pembelajaran Tematik muatan pelajaran IPA peserta didik Kelas V SD Negeri dengan pengaruh perlakuan kategori besar $(0,74)$.

4. Terdapat pengaruh yang signifikan secara statistik (taraf $a=5 \%$ ) model pembelajaran PjBL terhadap kemampuan berpikir orisinil (originality) dalam pembelajaran Tematik muatan pelajaran IPA peserta didik Kelas V SD Negeri dengan pengaruh perlakuan kategori besar $(0,59)$.

5. Terdapat pengaruh yang signifikan secara statistik (taraf a=5\%) model pembelajaran PjBL terhadap kemampuan berpikir merinci (elaboration) dalam pembelajaran Tematik muatan pelajaran IPA peserta didik Kelas V SD Negeri dengan pengaruh perlakuan kategori besar $(0,58)$.

6. Terdapat pengaruh yang signifikan secara statistik (taraf a=5\%) model pembelajaran PjBL terhadap kemampuan berpikir menilai (evaluation) dalam pembelajaran Tematik muatan pelajaran IPA peserta didik Kelas V SD Negeri dengan pengaruh perlakuan kategori besar $(0,60)$.

\section{Saran}

Berdasarkan hasil penelitian, pembahasan, dan kesimpulan maka peneliti menyampaikan beberapa saran berikut ini.

1. Penelitian ini menghasilkan karya pop up book 2 dimensi. Bagi Peneliti lain yang ingin menindaklanjuti penelitian ini disarankan untuk mencoba yang lebih baik seperti membuat karya pop up book 3 dimensi.

2. Dalam kemampuan berpikir lancar (fluency) pendidik perlumemberi reword kepada pesertadidik, agar berani mengemukakan pendapatnya didepan kelas

3. Dalam kemampuan berpikir luwes (flexibility), pendidikdisarankan lebih kreatif dalam menggali pengetahuan pesertadidik agar mampu melihat masalah dari sudut pandang yang berbeda-beda.

4. Dikarenakan tuntutan peserta didik untuk berpikir orisinil, (originality), berpikir merinci (elaboration) dan berpikir menilai (evaluation) pendidik perlu menambahkan sumber belajar yang relevan, sehingga pendidik mendapatkan wawasan yang lebih luas. Dan peserta didik mendapatkan informasi dan gagasan yang lebih kompleks.

\section{Referensi}

Abidin, Y. (2014). Desain Sistem Pembelajaran dalam Konteks Kurikulum 2013. Bandung: PT Refika Aditama.

Arisanti, W. O., Sopandi, W., \& Widodo, A. (2016). Analisis penguasaan konsep dan keterampilan berpikir kreatif siswa SD melalui Project Based Learning. Jurnal Pendidikan Dasar, 82-95.

Hosnan. (2014). Pendekatan Saintifik dan Kontekstual dalam Pembelajaran Abad 21. Bogor: Ghalia Indonesia.

Kusumaningrum, S., \& Djukri, D. (2016). Pengembangan Perangkat Pembelajaran Model Project Based Learning (PjBL) untuk Meningkatkan Keterampilan Proses Sains dan Kreativitas. Jurnal Inovasi Pendidikan IPA, 2 (2), 241 251.

Ngalimun. (2018). Strategi dan Model Pembelajaran. Yogyakarta: Aswaja pressindo.

Permendiknas No 41 tahun 2007. Tentang Standar Proses. 
Priansa, D. J. (2017). Pengembangan Strategi \& Model Pembelajaran Inovatif, Kreatif, dan Presntatif dalam Memahami Peserta didik. Bandung: CV. Pustaka Setia.

Safri, M., Sari, S. A., \& Marlina. (2017). Pengembangan Media Belajar Pop-Up BookPada Materi Minyak Bumi.Jurnal Pendidikan Sains Indonesia, 107. 113.

Siregar, E., \& Nara, H. (2014). Teori Belajar dan Pembelajaran. Bogor: Ghalia Indonesia.

Siswono, T. Y. (2018). Pembelajaran Matematika Berbasis Pengajuan dan Pemecahan Masalah. Bandung: PT.Remaja Rosdakarya.

Sulaeman, M. (2016). Aplikasi Project Based Learning (PBL) untuk Membangun Keterampilan Berpikir Kritis dan Kreatif Siswa . Jawa Barat: Bioma. 